\title{
Modern Condition of Coenopopulation of Tulipa fosteriana W. Irving in Southern Part of Uzbekistan
}

\section{Khujanazarov Uktam Eshtemirovich ${ }^{1}$, Habibullo Shomuradov², Sadinov Jasur Samandarovich ${ }^{1}$, Xidirova Mastura Abduxalimovna ${ }^{3}$}

${ }^{1}$ Department of Botany, Tashkent State Pedagogical University Named after Nizami Tashkent, Tashkent, Uzbekistan ${ }^{2}$ Department of Geobotany and Ecology, Botanical Institute of Academy Sciences of Uzbekistan, Tashkent, Uzbekistan ${ }^{3} 44^{\text {th }}$-Secondary School, Tashkent, Uzbekistan

Email: ^khuzhanazarov74@mail.ru

How to cite this paper: Eshtemirovich, K.U., Shomuradov, H., Samandarovich, S.J. and Abduxalimovna, X.M. (2020) Modern Condition of Coenopopulation of Tulipa fosteriana W. Irving in Southern Part of Uzbekistan. American Journal of Plant Sciences, 11, 832-837.

https://doi.org/10.4236/ajps.2020.116059

Received: May 5, 2019

Accepted: June 25, 2020

Published: June 28, 2020

Copyright () 2020 by author(s) and Scientific Research Publishing Inc. This work is licensed under the Creative Commons Attribution International License (CC BY 4.0).

http://creativecommons.org/licenses/by/4.0/

\begin{abstract}
This article reveals the data about two coenopopulation of Tulipa fosteriana in Zeravshan mountain ridge in the vicinity of the Takhta-Karachi pass in the border of Kashkadarya basin. Thus, the studied coenopopulation of T. fosteriana is normal, incomplete. The absence of senile individuals in the examined coenopopulation is associated with the biological characteristic of the species. In tulips, as in many geophytes, most individuals completely finish their large life cycles in a generative state. The ontogenetic spectra of the studied coenopopulation coincide with the characteristic ones, and thereby reflect the biological characteristics of the species.
\end{abstract}

\section{Keywords}

Tulipa Fosteriana, Pasture, Population, Community, Coenopopulation, Ecological-Phytocenotic Conditions, Zeravshan Ridges,

Amygdalus spinosissima, Ferula kuhistanica

\section{Introduction}

One of the leading branches of agriculture is animal husbandry, and it is important to conduct a scientific, practical study, assessment of the material source of its development-natural food (source of hay)—pasture types [1]. The types of pastures-natural territorial complexes with similar climate, soil, productivity (fertility), the time of year, when cattle are grazed and types, are determined by the edificatory types of plant families. There is a need to determine their ecolog- 
ical status: structure, composition, productivity (fertility), and degree of damage (degradation, transformation), types of damage factors (damage), and other quantitative and qualitative indicators [2]. The foothill and mountain pastures of the Kashkadarya Basin are one of the main bases for the development of animal husbandry, in recent years the productivity (fertility) of which is reduced under the influence of metrological factors [3] [4].

\section{Material and Methods}

Our research materials includes of Zeravshan mountain ridges and southern parts of Kashkadarya basin endemic plants. Field research was performed during June 2017 by traditional phytosociological methods with description of plant associations, collection of herbarium specimens and photographing of surveyed plots [5]. Demographic structure of populations was studied in accordance with T. A. Rabotnov [6], A. A. Uranov [7], L. A. Zhukova and E. V. Shestakova [8]. The age indexes were studied by A. A. Uranov [9]. The ontogenetic structure of coenopopulation in the different ecological and phytocenotical conditions was determined by the transect method [6] [9].

\section{Results}

During the research in southern part of Uzbekistan the current state of coenotic populations of 5 plant species, listed in the Red Book of the Republic of Uzbekistan in the territories of Kashkadarya region, such as Tulipa fosteriana W. Irving was studied. It should be noted that phytocenotic confinement and demographic state of the studied coenopopulation is described in more detail below.

Under different ecological and phytocenotic conditions of Zeravshan mountain ridge, two coenotic populations of $T$. fosteriana were studied (Figure 1). Both coenopopulation of the species were studied in Zeravshan mountain ridge in the vicinity of the Takhta-Karachi pass in the border of Kashkadarya basin. The first coenopopulation grows as a part of the herb-pink-rose community on the southeastern slope of Zeravshan mountain ridge along with coenopopulation Iris magnifica. As noted above, the soil of the described area is typical serozem, coarse-grained (Figure 1). The total projective cover of the grass consists of $75 \%$. The high density of grass stand is associated with the lack of anthropogenic impact (the described plot is located in a fenced area). In this case, the share of the studied species does not exceed $1 \%$. The floristic composition of the community consists of 27 species of vascular plants (Table 1).

The second coenopopulation of Tulipa fosteriana grows on eastern exposition of the separate part of the Zeravshan ridge as part of the Ferula-Amygdalus community. The soil of the described area is fine-grained, in some places stony. The total projective cover of the grass stand reaches to 51\%. Ferula kuhistanica and Amygdalus spinosissima dominate in the vegetation cover. The floristic composition of the community consists of 24 species of vascular plants (Table $1)$. 


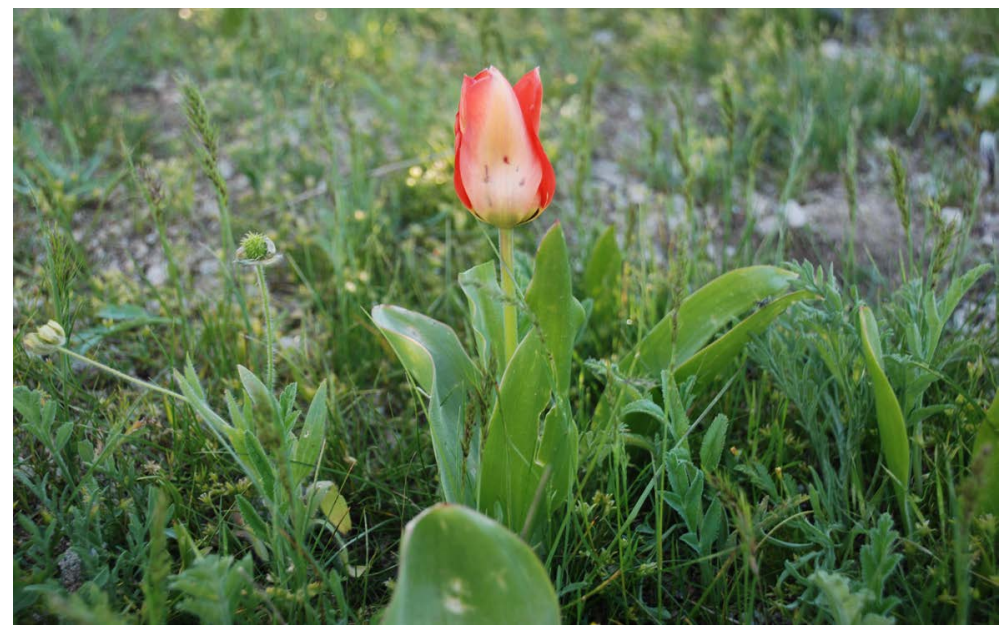

Figure 1. General form of Tulipa fosteriana.

Table 1. The species composition of the Ferula-Amygdalus community.

\begin{tabular}{|c|c|c|c|}
\hline No. & Name of plants & Life form & Projective cover, $\%$ \\
\hline 1 & Amygdalus spinosissima & shrub & 5 \\
\hline 2 & Amygdalus bucharica & shrub & 2 \\
\hline 3 & Cerasus erythrocarpa & shrub & 1 \\
\hline 4 & Acanthophyllum serawschanicum & shrub & + \\
\hline 5 & Ferula kuhistanica & perennial & 20 \\
\hline 6 & Ferula diversivittata & perennial & 2 \\
\hline 7 & Gagea capusii & perennial & + \\
\hline 8 & Gagea gageoides & perennial & + \\
\hline 9 & Tulipa fosteriana & perennial & 4 \\
\hline 10 & Tulipa turkestanica & perennial & + \\
\hline 11 & Astragalus sp. & perennial & + \\
\hline 12 & Scarioila orientalis & perennial & + \\
\hline 13 & Carydalis lededbouriana & perennial & + \\
\hline 14 & Iris stolonifera & perennial & + \\
\hline 15 & Allium pratense & perennial & + \\
\hline 16 & Hypericum perforatum & perennial & 4 \\
\hline 17 & Thymus seravschanicus & perennial & 2 \\
\hline 18 & Poa bulbosa & perennial & 5 \\
\hline 19 & Poa pratensis & perennial & 4 \\
\hline 20 & Centaurea squarrosa & perennial & 1 \\
\hline 21 & Cousinia radians & perennial & + \\
\hline 22 & Geranium pusillum & annual & + \\
\hline 23 & Ranunculus paucidentatus & annual & + \\
\hline 24 & Turgenia latifolia & annual & + \\
\hline
\end{tabular}


The ontogenetic structure of Tulipa fosteriana has not been previously studied. To assess the state of coenopopulation on the base of demographic indicators of coenopopulation, the collected data during the field studies were used in the current year. According to the classification of A. A. Uranov [7], the studied coenopopulation are normal, incomplete. Senile individuals are absent in the composition of both coenopopulation. The absence of senile plants in bulb coenopopulation is associated with the death of most individuals in generative ontogenetic states.

On the assumption of the peculiarities of the species biology (high seed productivity, the presence of vegetative reproduction due to stolons, the most slowed down rates of development of individuals in the virgin state), the characteristic spectrum of coenopopulation of this species will be the left-sided type with a peak in juvenile individuals. At the time of research, the ontogenetic spectrum as the first, so and coenopopulation in general coincides with the characteristic one (only the peak falls on immature individuals).

In the first coenopopulation, age groups are distributed as follows: juvenile-29.3\%, immature-57.2\%, virginal-9.3 and generative-only $4.1 \%$ (senile are absent), and in the second $31.0 \% ; 23.3 \% ; 41.2 \% ; 4.4 \%$ and $0.0 \%$, respectively.

The high value of juvenile individuals in the first coenopopulation is associated with high seed productivity of generative individuals and high seed germination. The predominance of immature individuals in the first coenopopulation is the result of the high survival rate of young individuals (juvenile) and the presence of vegetative reproduction due to stolons in an immature age state. But, due to the high pressure of competitive species, not all immature individuals pass to the virginal age state (Figure 2). A negligible percentage of generative individuals at the time of the research, of course, are associated with the collection of flowering plants in bouquets. We recall that both coenopopulation grow in the area of the Takhta-Karacha pass.

The ontogenetic spectrum of the second coenopopulation is also left-handed. The peak in the spectrum falls on virginal plants.

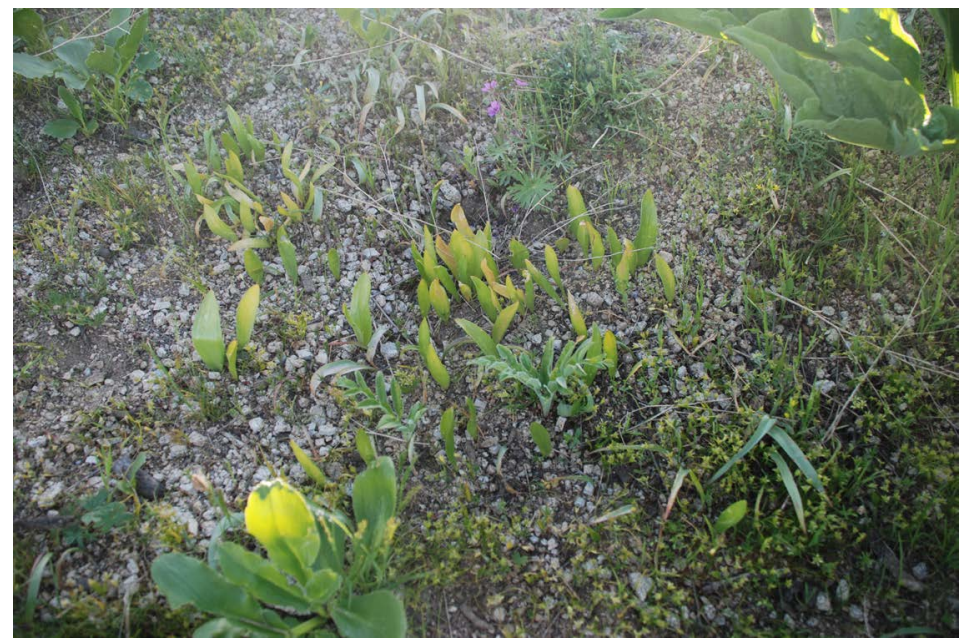

Figure 2. Virgin individuals. 
In this coenopopulation, as well as the previous one, the proportion of generative individuals is low. It does not exceed $4.4 \%$. The low proportion of generative individuals in coenopopulation is related with the recreational process.

Thus, the studied coenopopulation of $T$. fosteriana is normal, incomplete. The absence of senile individuals in the examined coenopopulation is associated with the biological characteristic of the species. In tulips, as in many geophytes, most individuals complete finish their large life cycles in a generative state. The ontogenetic spectra of the studied coenopopulation coincide with the characteristic ones, and thereby reflect the biological characteristics of the species.

\section{Conclusion}

In general, coenopopulation is in critical condition. This is facilitated by year-round grazing in this area. In general, this area is one of the key botanical territories of the Republic. Here, in addition to Allium jesdianum, such unique, narrow-local endemic species as Tulipa uzbekistanica, Allium botschantzevii, Eversmannia botschantzevi (endemic to the Zindansai river basin) and Salvia lilacinocoerulea and Hedysarum magnificum grow. In order to protect population of these unique species, local government and local population should control these areas by regulating pasture turnover.

\section{Conflicts of Interest}

The authors declare no conflicts of interest regarding the publication of this paper.

\section{References}

[1] Galnaityte, A. and Krisciukaitiene, I. (2017) Simulation of Sustainable Farming Practices Development in Lithuania. Public Policy and Administration, 16, 264-278.

[2] Sukhova, M.G., Zhuravleva, O.V., Vinokurov, Y.I., Chernova, E.O. and Kaizer, M.I. (2018) Recreation and Bioclimatic Specifics of Landscapes of the Central and South-Eastern Altai. Periodical Tche Quimica, 15, 537-547.

[3] Khujanazarov, U.E., Shomuradov, H. and Afonina, E.A. (2019) Modern Condition of Coenopopulation of Eremurus robustus Regel (Xanthorrhoeaceae) in Kashkadarya Basin, Uzbekistan. The Asian International Journal of Life Sciences, Philippine, Supplement 21, 1-11.

[4] Khuzhanazarov, U. (2012) Current State of the Pastures of the Upper Zone of the Kashkadarya Basin. Bulletin of Agrarian Science of Uzbekistan, 1-2, 111-114.

[5] Mirkin, B.M., Naumova, L.G. and Solomeshch, A.I. (2000) The Modern Science of Vegetation. Russian Federation, Logos, Moscow, 264.

[6] Rabotnov, T.A. (1950) Vital Cycle of Perennial Grassy Plants in Meadow. Proceedings BIN AN USSR, 6, 7-204.

[7] Uranov, A.A. (1975) Age Specter Phytocoenopopulation as Function of Time and Energetic Wave Processes. Scientific Lecture of Higher Schools. Biological Sciences, 2, 7-34. 
[8] Zhukova, L.A. and Shestakova, E.V. (1997) Ontogenetic Atlas of Medical Plants. Mari State University, Yoshkar-Ola, 240.

[9] Glotov, N.B. (1998) About Value of Parameters of Aged Structure of Population of Plants. Plant Life in Heterogenic Environment. Yoshkar-Ola, 1, 146-149. 